\title{
Raman Spectroscopy: an effective thermal marker in low temperature carbonaceous fold-thrust belts
}

\author{
D. K. MUIRHEAD ${ }^{* 1}$, C.E. BOND ${ }^{1}$, H. WATKINS ${ }^{1}$, R.W.H. BUTLER ${ }^{1}$ \\ A. SCHITO ${ }^{2}$, Z. CRAWFORD ${ }^{1}, \&$ A. MARPINO ${ }^{1}$, \\ ${ }^{1}$ Department of Geology and Petroleum Geology, School of Geosciences, University of Aberdeen, \\ Aberdeen $A B 24$ 3UE, UK. \\ ${ }^{2}$ Dipartimento di Scienze, Sezione di Scienze Geologiche, Università degli Studi Roma Tre, L.go S. \\ 7 Leonardo Murialdo 1, 00146, Roma, Italy
}

*Corresponding author (e-mail: dmuirhead@abdn.ac.uk)

Word count: 5780

Raman, low temperature, thrusts, foreland, folds, maturation

\begin{abstract}
:
Raman spectroscopy allows thermal maturation of carbonaceous sediments to be determined. The technique has been employed on metamorphic samples exceeding temperatures of $270{ }^{\circ} \mathrm{C}$, but recently has been shown to be effective at lower temperatures. Thermal maturation techniques commonly depend on sample size, have varying efficacies at different temperatures and in different conditions. The underlying processes are not well understood, thus data interpretation can be ambiguous. Here we show the efficacy of Raman as a low temperature thermal marker in a thrust belt. The Bornes region, French subalpine chain provides an opportunity to test the technique against published vitrinite reflectance data and thermal modelling for the first time. In doing so we show that Raman is an effective thermal marker to temperatures as low as $75{ }^{\circ} \mathrm{C}$, has a small error and is consistent with previous work. The Raman data allows us to postulate the relative thickness of the sedimentary succession across the chain, timing of thermal maturation and timing and thickness variations of the over-thrust Prealpine nappe. The work establishes Raman as a low temperature thermal marker for correlation with other techniques to ensure effective and robust interpretation, that can readily be applied to fold-thrust belts in hydrocarbon provinces.
\end{abstract}

\section{Introduction}

Structural interpretations of foreland fold and thrust belts can be challenging. This is because they are commonly driven by limited information on subsurface structural geometry. Even in well-imaged examples, determinations of structural histories commonly rely on idealised and theoretical models of thrust belt evolution such as an assumed sequence of thrust sheet stacking (Butler et al, 2018; Balestra et al, 2019). However, determinations of the temperature histories of rocks in thrust systems can provide tests of structural evolution, and are of course critical for assessing hydrocarbon prospectivity. Although various low-temperature thermal markers are in use (e.g. illite crystallinitity in mud-rocks, vitrinite reflectance on organic materials), these techniques are not in general use in thrust belt studies. Perhaps this reflects complexities in sampling, preparation and analytical methods. In contrast, Raman spectroscopy of organic material is a rapid, non-destructive and cost-efficient technique for establishing the peak temperature experienced by carbonaceous rocks to quantify peak 
palaeotemperatures in the range of $200^{\circ} \mathrm{C}-400^{\circ} \mathrm{C}$. While these applications are important, the temperature ranges exceed both those for hydrocarbon generation and for general conditions typical of foreland thrust belts. If Raman spectroscopy can be applied to lower temperatures it opens the door to the routine determination of thermal histories in foreland thrust belts. Therefore, our aim here is demonstrate the application of the Raman technique to temperatures that embrace the oil and gas generation windows and in doing so, establish the method as an ideal tool for understanding the thermal evolution of foreland fold and thrust belts.

Knowledge of the peak thermal maturity of sedimentary formations is critical to our understanding of the thermal alteration of organic matter as a result of burial due to folding and thrusting (Bustin, 1991; Echavarria et al. 2008; Aldega et al., 2014); hydrocarbon potential of local source rock intervals (Schito et al., 2017; Muirhead et al, 2017; Lupoi et al., 2018) and potential reservoir quality assessments. Calibrating thermal history in thrust systems is especially important, especially in establishing the temporal relationships between hydrocarbon maturation, charge and trap formation. While this information is important for de-risking hydrocarbon exploration, it also helps to constrain understanding of tectonic histories, by informing quantitative estimates of burial depths, their duration and in quantifying denudation processes.

Thermal maturity is commonly determined using multiple methods, allowing calibration between techniques, to constrain peak temperatures. Single technique use suffers from a range of issues. Vitrinite reflectance often quoted as the most robust thermal maturation marker technique can be affected by the organic facies, as well as temperature and pressure conditions (Schito et al. 2016). These issues lead to uncertainties in interpretation and associated thermal calibration. Many authors report Ro suppression or retardation, particularly at lower thermal maturities (Ro $\leq 1.0 \%$ ) (e.g. McTavish, 1978; Hutton and Cook, 1980; Li et al., 2004, Barker et al., 2007; Schito et al, 2016). Hackley et al. (2013) interpret this as the result of inclusion of solid bitumen in analysis as well as vitrinite. Hackley and Lewan (2018) go further and assert that known issues with vitrinite reflectance in pre-Palaeozoic sediments maybe the result of such mistaken identity. Irrespective of the cause, care in interpretation is often required and calibration against other techniques is an obvious test to ensure robust interpretation. For example Schito et al. (2016) show that smectite illitization is a more robust thermal marker in the Congo Basin than vitrinite reflectance due to the issues outlined. Establishing Raman spectroscopy as an alternative technique to corroborate, or otherwise, vitrinite reflectance data at low temperatures therefore has significant benefits for interpretation of thermal maturity, particularly for hydrocarbon generation.

We have chosen to apply Raman spectroscopy to samples collected from part the NW Subalpine thrust belt of France for the following reasons: the setting has already yielded palaeothermal estimates derived from traditional methods (e.g. vitrinite reflectance - Moss, 1992; Deville \& Sassi, 2005); thrust structures and burial conditions are complex, thus providing a range of materials that experienced different thermal histories; there are existing 1D (Butler 1991) and 2D (Deville \& Sassi 2005) thermal models for the stratigraphic and tectonic burial histories. Raman spectroscopy has already been used to develop thermal profiles in once-deeply buried parts of the Western Alps across exhumed sedimentary sequences, including through complex inverted basin systems (e.g. Bellahsen et al, 2014; Nibourel et al. 2018). These existing applications have addressed peak temperatures in the range of $280{ }^{\circ} \mathrm{C}$ to $400{ }^{\circ} \mathrm{C}$, so, while demonstrating that the technique works - they do not inform those modelling petroleum systems or the evolution of the external Alpine thrust systems. 


\section{Raman Spectroscopy of Carbonaceous Materials}

Raman spectroscopy is based on the so called "Raman scattering" that is due to various elementary excitations where the energy is lost or gained during the scattering process. For this reason Raman spectra can be used as "fingerprint" for different materials. Analysis of the Raman spectra in carbonaceous material are used to derive the maximum temperature of a sample, up to $650^{\circ} \mathrm{C}$ (Beyssac et al. 2002). Fossil carbonaceous materials within rocks undergo a complex series of reactions when thermally altered, which involve both the formation and reordering of aromatic sub-units towards stacked layers such as graphite. Raman spectroscopy has been widely used (Tuinstra \& Koenig 1970; Landis 1971; Nemanich \& Solin 1979; Knight \& White 1989; Ferrari \& Robertson 2001; Beyssac et al. 2002) as a powerful, non-destructive tool for evaluating the characterisation and thermal alteration of diverse forms of carbonaceous matter (crystalline, nanocrystalline, amorphous). Measurement of spectroscopic parameters, are mainly based on two broad first order Raman bands (spectral peaks) at $\sim 1585 \mathrm{~cm}^{-1}$ (the graphite peak , G) and $1350 \mathrm{~cm}^{-1}$ (the disorder peak, D) (Fig. 1). These bands represent the inelastic scattering (Stokes Raman scattering) produced by electronic and photonic induced laser irradiation. Due to the physical properties of carbonaceous materials that are based on the hybridised atomic orbital configuration of carbon atoms (Robertson 1991), the shape and relative intensities of the $\mathrm{D}$ and $\mathrm{G}$ bands reflect the ratio of $\mathrm{sp}^{2}$ (graphite-like, trigonal planar symmetry) and $\mathrm{sp}^{3}$ (diamond-like, tetrahedral symmetry) carbon bonds (Robertson 1991). The $\mathrm{G}$ band is assigned to the in-plane vibration of the carbon atoms in the graphene sheets and the $D$ band either by double resonant Raman scattering or has been related to the ring breathing vibration in the graphite sub-unit or polycyclic aromatic compounds (Negri et al., 2002, 2004; Castiglioni et al., 2004; Di Donato et al., 2004; Lünsdorf, 2016)).

The $\sim 1585 \mathrm{~cm}^{-1}$ graphite peak is a composite of several Raman bands at $1615 \mathrm{~cm}^{-1}, \sim 1598 \mathrm{~cm}^{-1}$ and $1545 \mathrm{~cm}^{-1}$ (D2, G, D3 respectively) and is treated as one spectral peak in disordered materials until the band narrows, through increasing thermal alteration, to allow clear definition of the shouldered disorder peaks (Fig. 1). Peak deconvolution is performed on the composite $\mathrm{G}$ band, as it is not possible to separate the $\mathrm{G}$ and D2 bands in poorly organised carbon or low-grade rocks (Beyssac et al. 2002; Brolly et al 2016) such as those in this study. A number of Raman parameters have been developed over the past few decades that involve measurements made on Raman spectral peaks. Wopenka \& Pasteris (1993) measured the position and width of the $G$ peak at $1585 \mathrm{~cm}^{-1}$ for a suite of metamorphic zones. Increased thermal maturation lead to the structural reordering of carbonaceous materials, with an increase in the proportion of aromatic carbon, in turn narrowing the $G$ band and shifting it closer towards $1615 \mathrm{~cm}^{-1}$. If samples are graphitic, narrowing remains similar but with $\mathrm{G}$ peak position shifted downwards to $\sim 1598 \mathrm{~cm}^{-1}$. It is important to note that in amorphous carbon $(a-C)$ initial development of a $D$ band indicates ordering, whereas in graphitic carbon $(t a-C)$, the presence of a $D$ band indicates disorder, so Raman parameters must be interpreted with respect to any known information about the carbon feedstock (Ferrari \& Robertson, 2001).

The D/G-peak ratios ( $I_{D} / I_{G}$ (Intensity [peak height]), $A_{D} / A_{G}$ (Area)) (Fig. 1) decrease with significant thermal maturation and increased structural ordering (Yui et al. 1996; Bonal et al. 2006; Busemann et al. 2007; Quirico et al. 2009) Plotting of these two ratios can reveal differences in the thermal alteration of the carbonaceous materials (Pasteris \& Wopenka, 1991; Jehlicka \& Bény, 1992). Early stage thermal alteration can, however, raise the $I_{D} / I_{G}$ parameter, particularly in relatively homogeneous samples (Rouzaud et al. 1983; Muirhead et al. 2012).

Correlations between Raman parameters and thermal maturity have been proposed from early maturation up to over-mature stages of hydrocarbon generation based on analyses performed on 
coals (Quirico et al., 2005; Li, 2007; Marques et al., 2009; Guedes et al., 2010; 2012; Potgieter-Vermaak et al., 2001; Hinrichs et al., 2016; Lupoi et al., 2017), dispersed organic matter, Paleozoic organic matter and solid bitumen (Liu et al., 2012; Romero-Sarmiento et al., 2014; Zhou et al., 2014; Lunsdorf, 2016; Mumm and Inan, 2016). These methods are applicable to samples that have attained temperatures greater than approximately $270^{\circ} \mathrm{C}$ (Wopenka \& Pasteris, 1993; Beysaac et al, 2002;. Rahl et al, 2005; Molli et al 2018). Robust correlations for low maturity, lower than $300^{\circ} \mathrm{C}$, organic carbon have only recently been established (Wilkins et al. in 2014, Hinrichs et al., 2016; Schmidt et al., 2017; Lupoi et al., 2017; Schito et al., 2017; Muirhead et al, 2017; Schito and Corrado 2018; Muirhead at al., 2018; Henry et al 2018). Many authors have demonstrated that the position (Kelemen and Fang, 2001; Liu et al., 2012; Wilkins et al., 2014; 2017; Mum and Inan, 2016; Lupoi et al., 2017) or the area/width ratios of the Raman D and G bands (Guedes et al., 2010, 2012; Quirico et al., 2010; Hinrichs et al., 2014; Lünsdorf, 2016; Muirhead et al, 2017; Schito et al., 2017; Schmidt et al., 2017; Schito and Corrado, 2018; Muirhead et al, 2018) vary as a function of thermal maturity in the immature stages of hydrocarbon generation. There is agreement that the main changes in organic matter Raman spectra at low maturity exhibit a narrowing of the $G$ band and an increase of the $D$ band area with thermal maturity increase.

Several factors make Raman spectroscopy ideal for thermal maturation studies: the degree of order of carbonaceous materials is not affected by retrogression, can be applied to any carbonaceous materials and is not restricted to specific geological time periods (unlike vitrinite reflectance), has little limitation with respect to carbon sample size, even sedimentary rocks with very low $0.09 \%$ total organic carbon concentrations are amenable to Raman spectroscopy (Muirhead et al. 2017), and finally it is also a non-destructive technique that benefits from relatively quick sample preparation and analysis times. Previous Raman spectroscopy studies on low temperature $\left(<300{ }^{\circ} \mathrm{C}\right)$ carbonaceous samples have focused on characterisation of organic matter in clastic sediments. Here we use these newly established correlations for Raman spectroscopy at low temperatures and apply them to carbonaceous sedimentary horizons in the Subalpine chain thrust stack, to test the efficacy of Raman spectroscopy at low temperatures $\left(75-300^{\circ} \mathrm{C}\right)$ and to delineate burial induced thermal maturation. We validate our results against the existing vitrinite reflectance and thermal modelling work.

\section{Geological context}

The French Subalpine chains are part of the External Western Alps and form a chain of fold-thrust structures that can be traced for over $200 \mathrm{~km}$ from the Swiss border in the NNE, to south of Grenoble in the SSW. The Subalpine chains are subdivided into constituent "massifs" that represent along-strike equivalence. From south to north these are: the Vercors, Chartreuse, Bauges and the Bornes-Aravis and Haute Giffre regions (Fig. 2). The regional structure varies along the system (Doudoux et al. 1982; Graiter 1989; Butler 1992; Deville \& Sassi 2005). The thrusting direction was generally towards the WNW in this sector of the Alpine chain, with thrusts active in late Miocene times. Post to late-orogenic rebound has uplifted the thrust system through Plio-Quaternary time .

The Subalpine chains are chiefly composed of Mesozoic limestones and shales that accumulated on the edge of the Tethyan ocean and associated basins (as reviewed by de Graciansky et al. 2011). Their thickness varies regionally, generally increasing from West to East, reaching values of c. 5-6 km in the main depo-centres. Collectively these strata are organised into a mechanical multilayer within which a series of intervals of platform carbonates form competent layers. The youngest of these is the Urgonian limestone (Hauterivian-Barremian) but other important limestone packages underlie this unit. The Tithonian limestone - a regional marker bed indicative of especially high carbonate 
production, is found throughout the region. It is generally interpreted to form the base of the "postrift" mega-sequence (e.g. Lemoine et al. 1986). Post-rift subsidence in the Subalpine region is chiefly under-supplied by sediment so that most of the Cretaceous deposits are open-marine marls. However, carbonate platforms built into this accommodation space, advancing from the weakly subsiding European continent (now represented by the Jura hills). The Urgonian represents one of these platform developments.

The underlying Jurassic strata represent the syn-rift. In the eastern subalps these achieve thicknesses of $>2 \mathrm{~km}$ and are chiefly open-marine marls and calc-turbidites. A few metres of Triassic strata represent the pre-rift sediments which lie unconformably on Palaeozoic basement (chiefly crystalline, but with local relicts of Carboniferous strata). The Triassic units include evaporites which form a regional detachment horizon that transferred Alpine displacements ahead of the chain and beneath the outlying Jura fold belt. The Subalpine chains represent an intermediate setting, between the Jura and the main Alpine mountains.

Overlying the Mesozoic rocks of the former Tethyan margin are a series of siliciclastics that represent the deposits of the ancestral Alpine foredeep (e.g. Sissingh 2001). A vestigial part of the foredeep constitutes the Annecy basin, preserved between the Subalps and Jura. The Miocene foredeep deposits are chiefly very shallow-marine sandstones which achieve thicknesses of about $2 \mathrm{~km}$. Further east the ancestral foredeep fill is represented by Eo-Oligocene turbidites. These are best-preserved in the northern part of the NW subalps. Estimating a true stratigraphic thickness for these older foredeep strata is difficult because the succession is capped by far-travelled thrust sheets, now preserved in the so-called Prealpine klippen. The original extent of the Prealpine thrust sheet over the subalpine chains was inferred using branch line mapping by Butler (1989). In our study area, the frontal parts of the Bornes and Bauges massifs remain un-buried by the thrust sheet.

The complex structural arrangement of the northern part of the NW Subalps provides an ideal context for examining the thermal consequences of thrusting as a range of burial conditions can be explored from the system. Consequently our case study comes from the Subalpine chains around the city of Annecy, in the Bornes and Bauges regions. This site was examined by Butler (1991) in his study of tectonically-driven hydrocarbon maturation. Further context and geological notes are provided there. Subsequently, Moss (1992) measured vitrinite reflectance through the region. Further palaeo-thermal data, and thrust-thermal modelling is provided by Deville \& Sassi (2005).

\section{Structural geometry}

Two cross sections (Fig. 3) have been constructed through the Bornes and northern Bauges regions to illustrate the main structures in the area and the present day configuration of units. Both cross sections are oriented ESE-WNW (110-290 $)$; this orientation is the average bedding dip direction within the study area, and depicts structural geometries in a plane parallel to the direction of compression. Section A-A' (Fig. 3) runs through the central Bornes and section B-B' (Fig. 3) runs through the southern Bornes and northern Bauges. Thrust sheets at the western ends of the cross sections contain relatively thin stratigraphy compared to the eastern ends, and are inferred to rest directly on top of the crystalline basement. In the central portion of the cross sections the thrust sheet is inferred to be elevated above regional by stacking on top of a lower thrust sheet (the Semnoz thrust sheet (S), Fig. 3). Folds in the central portion of the cross sections have tight geometries and thrusting within the thrust sheet is rare, rather deformation is accommodated by internal folding. Further east is the Thones depression; a region of low topography with limited folding in the Mesozoic succession (Fig. 3). At the eastern ends of the cross sections is the Araviz Ridge (AR, Fig. 3), comprising of west-dipping Mesozoic-Cenozoic units that are inferred to have been uplifted above their regionals by inversion of 
a basement-involved fault beneath. On top of the Thones depression (TD, Figure 2) and Araviz Ridge is the Prealpine Nappe (Fig. 3), which is thought to have been emplaced from the east. The thickness and internal geometry of this nappe are poorly constrained so representation in the cross sections (figure 3) should be considered indicative, although the Raman spectroscopy data presented indicate both the presence of the nappe and thickening of it to the east.

\section{Methodology}

Sample selection

Representative samples from the Mesozoic-Cenozoic succession targeting limestones and shales from the Cenozoic (Oligocene, Eocene) and Mesozoic (Mid Jurassic - Bathonian-Callovian; Late Jurassic Oxfordian, Kimmeridgian-Tithonian; Early Cretaceous - Berrasian-Valangiaian, Hauterivian,Barremian) were collected from 18 localities across the study area (Table 1; Fig. 2; Fig. 3). These sites were selected to give the best possible geographic coverage of the study area whilst sampling the main Veyrier Thrust panel. Samples were collected away from faults, thrusts or other phenomena that could have altered the organic materials. Organic materials within the samples were targeted for analysis. Data for crosssection construction was collected alongside the sampling with structural data collection focused on accessible transect lines. Field data were combined with data from the regional BRGM map sheets..

\section{Total Organic Carbon (TOC) analysis}

Rock samples ( $\sim 30 \mathrm{~g}$ ) were powdered and treated with hydrochloric acid (10 and $25 \% \mathrm{v} / \mathrm{v}$ ) in order to remove any carbonate. The dried weight of the recovered material was recorded. The total organic carbon content was calculated using the method outlined by Gross (1971), where wt\% C was measured with a Carbon-Sulfur analyzer (LECO CS225) at the University of Aberdeen.

\section{Kerogen isolation and Raman spectrometry}

Further treatment of the carbonate-free residue with hydrofluoric acid $(40 \% \mathrm{v} / \mathrm{v})$ yielded a kerogen concentrate suitable for analysis by Raman spectrometry. Raman measurements were performed on a Renishaw inVia reflex Raman spectrometer at the University of Aberdeen. A Leica DMLM reflected light microscope was used to focus the $\mathrm{Ar}^{+}$green laser (wavelength $514.5 \mathrm{~nm}$ ). The laser spot size was approximately $1-2 \mu \mathrm{m}$ and laser power between $10-50 \%$ ( $<13 \mathrm{~mW}$ power at the sample). The scattered light was dispersed and recorded by means of a CCD (Charge Coupled Device) detector. Data were collected between $1100 \mathrm{~cm}^{-1}$ and $1700 \mathrm{~cm}^{-1}$ with a spectral resolution less than $3 \mathrm{~cm}^{-1}$. The duration of accumulations was typically up to 10 seconds for between 3 and 5 accumulations.

The Renishaw WiRE 3.0 curve-fit software was used for spectral deconvolution. Smoothing and baseline extractions were performed on each sample, including a cubic spline interpolation. Each sample was deconvolved and data extracted at least three times to ensure reproducibility and the removal of any background signal. Peak position and peak full width at half maximum (FWHM) (Fig. 3) are measured in wavenumbers $\left(\mathrm{cm}^{-1}\right)$, which records the change in vibrational frequency (stretching and breathing) of the Raman-active carbon molecules. Minimal spectral processing and deconvolution was applied to the measurement of peak areas, with composite $G$ and $D$ bands used to calculate $I_{D} / I_{G}$ ratios as outlined in Muirhead et al., (2012; 2016). Prior to analysis of deconvolved spectra, an initial visual approach to spectral interpretation was adopted (Coates 2000; Henry et al 2018). 
Peak temperatures were calculated from the parameters carried out from the peak fitting were used to calculate vitrinite reflectance equivalent and thus temperature (according to Barker and Pawlewicz's equation, 1986) using the multi-parametric equations proposed by Schito and Corrado (2018); equations and example calculation are shown in figure 1c. Calculated temperatures are rounded to the nearest $5^{\circ} \mathrm{C}$ and displayed in Table 1 and Figure 6 . The automated deconvolution was performed using the peakfit programme modified after O'Haver (2015).

\section{Results}

\section{Data and key observations}

The results of the TOC and Raman spectroscopic analyses are given in Table 1. Representative stacked first order Raman spectra from across the region are displayed in Figure 4. There is a distinct narrowing of the $G$ band and increase of the $D$ band widths and intensity (height) (and thus increase of $D$ band area) in the samples proceeding to the Southeast (e.g. from samples 1, 2, 7 to 8, 17, 9; see Figure 4) . Raman data from across the region, plot adjacent to or within the kerogen field of Wopenka \& Pasteris (1993), and well away from the graphite field (Figure 5, and inset). Deconvolved data for the samples studied exhibit a shift towards higher $G$ band wavelengths (peak position: $\left.\left(W_{G}\left(\mathrm{~cm}^{-1}\right)\right)\right)$ and a reduction in $\mathrm{G}$ band full width at half maximum (FWHM) (Fig 5). This is consistent with an increase in thermal maturity in early stage alteration, i.e. prior to any graphitisation (Sandford et al, 2006; Muirhead et al, 2012; 2017). The lowest $I_{D} / I_{G}$ ratio observed, 0.21 , was within the most North-westerly samples (Table 1) compared to the highest $I_{D} / I_{G}$ ratio of 0.66 from the most South-easterly samples. These parameters and ratios rise moving toward their maximum in the South-East (Table 1). Typically high maturity leads to a decrease in the $I_{D} / I_{G}$ ratio, $\mathrm{D}$ band area and width and is indicative of an increase in thermal maturation and structural ordering (Yui et al, 1986; Busemann et al, 2007). However, early stage thermal alteration can raise these ratios (Rouzaud et al, 1983; Muirhead et al, 2012, 2017), as evidenced in the data presented here, with the South-easterly samples exhibiting, for example, a higher $I_{D} / I_{G}$ ratio than in the Northwest. (Table 1). As expected, there is no consistent relationship between the Raman parameters and the abundance of carbon (\%TOC) (Table 1).

\section{Temperatures and structural position}

Temperatures calculated from the Raman data (Table 1) using vitrinite reflectance equivalence (see methodology; Fig. 1) are plotted on the two cross-sections that cut the study area (Figure 3). The results show, as expected, increasing thermal maturity and temperature from the foreland to the hinterland of the fold-thrust belt, west north west to east south east, with as predicted minimal foldthrust related burial in the foreland and greater burial in the hinterland. At the front of the range to the north of Annecy the lowest temperatures $\left(75^{\circ} \mathrm{C}\right)$ are recorded, cross section A-A' figure 3 , in Cenozoic sediments on the first fold-thrust pair to makes a surface expression. A lower thrust sheet, the Revard thrust, is predicted from emergent frontal structures to the south, that plunge northwards, but here this structure is draped by the overlying Cenozoic stratigraphy. Sediments lower in the stratigraphic succession (Berrasian-Valanginian, Hauterivian), that crop out along the section line to the east south east record calculated temperatures of $90-100{ }^{\circ} \mathrm{C}$ respectively. In the Thones Depression, the Cenozoic strata temperatures here are $115^{\circ} \mathrm{C}$, increasing to $125^{\circ} \mathrm{C}$. In sediments from the deepest part of the stratigraphy sampled, the Mid-Late Jurassic strata at the west north west end of the section $\left(A^{\prime}\right)$, below the pre-alpine nappe and above a possible basement inversion, temperatures are predicted to be $300^{\circ} \mathrm{C}$. 
In section B-B' (figure 3), approximately $15 \mathrm{~km}$ to the south similar trends are seen. In this section temperatures from the very frontal structures have not been sampled, but samples from the equivalent position and in the Veyrier thrust sheet as in section A-A' give similar temperatures of 100$120^{\circ} \mathrm{C}$. At the west north west end of the section the Mid-Late Jurassic beneath the pre-alpine nappe is again sampled. Calculated temperatures are $260^{\circ} \mathrm{C}, 40^{\circ} \mathrm{C}$ lower than those in the same position to the north. It is postulated that this temperature difference is due to the pre-alpine nappe tapering out to the South resulting in a thinner sequence of Triassic-Oligocene units, over thrusting the Mesozoic strata.

\section{Technique Validation}

In order to compare our data to the work of others we plot it spatially located on the geological map alongside the previous work of Moss (1992) and Deville \& Sassi (2006) for the same area (Figure 6). In doing so we aim to verify the application of Raman spectroscopy to low temperature $\left(75-300{ }^{\circ} \mathrm{C}\right)$ thermal maturity studies in carbonaceous materials; and to prove its efficacy as a thermal marker that in turn can be used to validate other thermal maturity techniques currently used in both basin and fold-thrust belt burial studies. Figure 6 shows data from this study and the actual data from Moss (1992) and Deville \& Sassi (2006), alongside their putative oil window and over mature zones. There is agreement across the region with respect to increasing temperature from the foreland to the hinterland between the Raman data, this study, and the vitrinite reflectance (\%Ro) data from previous work. Although, not shown in figure 6 these data also correspond to the \%Ro contours derived by the early work of Kübler (1979). Overall, the data matches exceptionally well with temperature differences of $<5{ }^{\circ} \mathrm{C}$ in many places, on adjacent samples analysed by different authors. Two samples by Moss (1992) show variation in the Oligocene, Cenozoic sediments. A sample with a $0.54 \%$ Ro and a calculated temperature of $86^{\circ} \mathrm{C}$, appears low compared to surrounding temperatures in the same Cenozoic strata of $116^{\circ} \mathrm{C}$ and $115^{\circ} \mathrm{C}$. The second sample, also from Oligocene strata with a $0.75 \%$ Ro sits underneath the mapped Prealpine klippe, with a calculated temperature of $112^{\circ} \mathrm{C}$. These variations suggest differences in the role and thickness of the overthrust strata of the Prealpine klippe across the Cenozoic succession. This is discussed in more detail below.

\section{Discussion}

The data presented in this study shows a systematic trend of increasing thermal maturity (maximum temperature) from lower temperatures in the north west, at the front of the fold-thrust belt to higher temperatures in the south east. The temperatures derived from the Raman spectroscopic analysis are consistent along the section lines (c. $40 \mathrm{~km}$ ), with adjacent samples showing the same, or similar temperature calculations; and conform to the general trend of temperature increase to the east south east. This is mirrored in the adjacent sections $A-A^{\prime}$ and $B-B^{\prime}$, separated by $c .15 \mathrm{~km}$ of fold-thrust belt, with consistent trends and temperatures in the sampled lithologies and thrust sheets across this distance, which can be correlated to structural position. We interpret consistent, but small increases in temperature within the Veriyer thrust sheet, in both cross-sections A-A' and B-B' over a distance of approximately $2 \mathrm{~km}$, as resulting from thickening of the stratigraphic sequence during deposition in fault bounded basins (Leimone et al. 1986) with a depo-centre towards the east south east. The subtle but consistent changes in calculated temperature suggest that there is enough precision in the Raman spectroscopy technique and associated temperature conversion to identify temperature differences in the order of $5-10^{\circ} \mathrm{C}$. Analytical errors associated with the temperatures calculated from the Raman data (range from $+/-5^{\circ} \mathrm{C}$ to $+/-20^{\circ} \mathrm{C}$ for individual samples, see Table 1 ) are consistent, or an 
improvement upon, other palaeotemperature techniques. The Raman spectroscopy data shows both consistency and precision in predicting thermal maturity and temperature.

\section{Implications for structural geometry and evolution}

Our data suggest that the thickness of Mesozoic, Cenozoic and Miocene strata deposited in basins deepening to the east was enough to expose the Mesozoic and Cenozoic strata to temperatures above $90^{\circ} \mathrm{C}$ and into thermal maturity, exceeding the oil-in window during basin formation (Figure 6). Temperatures calculated from the Raman analysis fall within the range proposed by (Kübler, 1991) and predicted from burial modelling (Butler, 1991), and from previous calculations based on vitrinite reflectance data and modelling (Moss, 1992; Deville and Sassi 2006). The observed temperature changes are predicted by the 1D modelling of Butler (1991) and are consistent with the vitrinite reflectance data of Moss (1992) and Deville and Sassi (2005). Although outwith the scope of this study, these data could be incorporated into new and more robust basin models for fold-thrust belts.

\section{Extent of the Prealpine nappe}

Given the mapped extent of the Prealpine nappe klippe (Figure 2) we know that samples 7 and 8 (Figure 3 ) of the Cenozoic strata, most likely lie beneath the nappe. These samples give maximum temperatures of 115 and $125^{\circ} \mathrm{C}$ respectively. One sample from Moss (1992) also samples the CenozoicOligocene strata from beneath the Prealpine nappe at its eastern side, and gives a temperature of 112 ${ }^{\circ} \mathrm{C}$ (Figure 6). The same temperature, of $112{ }^{\circ} \mathrm{C}$ from Oligocene strata at the western side of the nappe is obtained by both Moss (1992) and Deville and Sassi (2006), and similarly slightly further north in the same strata and at the western side of the mapped outcrop of the Prealpine nappe they both report $\%$ Ro values equating to a temperature of $116^{\circ} \mathrm{C}$ (Figure 6). Together, these data suggest a thin slice of nappe covers the sedimentary succession in this area, thickening slightly to the north, but consistent in thickness from NW-SE where it is mapped as a klippe. Our data suggests a maximum Cenozoic temperature of $100{ }^{\circ} \mathrm{C}$ in front of the prealpine nappe so the thickness of the Prealpine nappe here must be in the order of $0.5 \mathrm{~km}$ thickening northwards to upto $1 \mathrm{~km}$ to obtain temperatures of $125^{\circ} \mathrm{C}$ in the Cenozoic sediments to the north (Figure 7). If the temperature of $86^{\circ} \mathrm{C}$ in Cenozoic strata from Moss (1992) just to the north and west of the klippe (see Figure 6) is correct then the nappe must be interpreted as not extending over the Cenozoic strata here. So the klippe, more or less, represents the westward extent of the nappe, as predicted by Butler (1989).

\section{Thickness of the Prealpine nappe}

To the east of the Aravis Ridge a temperature increase is seen in the interpreted Raman data (Figure 6). The temperature change over a horizontal distance of $<10 \mathrm{~km}$ from $125^{\circ} \mathrm{C}$ in Cenozoic sediments to $300{ }^{\circ} \mathrm{C}$ in Mid-Late Jurassic, Mesozoic sediments. If a thermal gradient of $28{ }^{\circ} \mathrm{C} \mathrm{km}^{-1}$ is assumed and considered typical of this setting (after Butler, 1991) this would equate to $10-11 \mathrm{~km}$ of sediment thickness on top of the Mid-Late Jurassic strata. The sediments that record a maximum temperature of $300^{\circ} \mathrm{C}$, and those recording a temperature of $260^{\circ} \mathrm{C}$ to the south, sit above the triangle zone (Figure 3 , at the eastern end of the cross-sections), in which a basement wedge and potential back-thrusts are interpreted as lifting the stratigraphy above regional. But why such a dramatic increase in temperature? Two models are potentially viable. The first one in which the basement wedge is an inverted normal fault, i.e. a significant basin bounding fault off-setting basement in the Mid-Late Jurassic that allowed for thickening of the stratigraphy, not shown in the cross-sections in figure 2 and hard to accommodate with the known surface geology, which supports only gradual thickening of the known stratigraphic succession to the South east. The alternative is thickening of the Prealpine nappe. 
Our only other data point from the Mid-Late Jurassic sequence below the Tithonian in front of the predicted Prealpine nappe gives a maximum temperature of $120^{\circ} \mathrm{C}$, this suggests a thickening of the Prealpine nappe to $5 \mathrm{~km}$ in the southern Bornes and upto $6.4 \mathrm{~km} \mathrm{c.} 10 \mathrm{~km}$ north (Figure 7). Our data suggests that the Prealpine nappe thickens eastwards by $4.5-5.4 \mathrm{~km}$ over a horizontal distance of 10 $\mathrm{km}$, from the klippe (where we predict a thickness of $0.5 \mathrm{~km}$ ). We assume this thickening is accommodated by internal folding and thrusting in the nappe. Other authors come to similar conclusions with Butler (1991) modelling 4-4.5 km of load and Moss (1992) suggesting a Prealpine nappe upto $5 \mathrm{~km}$ thick in the Bornes area.

\section{Raman spectroscopy of carbon at low temperatures}

The Raman data follows a similar pattern to that presented by other authors for low temperature carbonaceous material. An increase in $\mathrm{G}$ band wavelength, $\mathrm{D}$ band intensity and $\mathrm{D}$ band area with increase in $\mathrm{G}$ band position in this study are consistent with other works on low maturity carbonaceous materials (Rouzaud et al, 1983; Sandford et al, 2006; Guedes et al., 2010, 2012; Quirico et al., 2010; Muirhead et al, 2012; Hinrichs et al., 2014; Lünsdorf, 2016; Muirhead et al, 2017; Schito et al., 2017; Schmidt et al., 2017; Schito and Corrado, 2018; Muirhead et al, 2018). Similarly, transition towards higher maturity materials exhibits a narrowing of the $\mathrm{G}$ band width, decrease in $\mathrm{G}$ band position and decrease in D band area, consistent with work from Yui et al. (1986); Wopenka \& Pasteris (1993); Beyssac et al. (2002); Busemann et a.l (2007); Lahfid et al. (2010); Rahl et al. (2015). This consistency adds weight to the argument for use of Raman spectroscopy as a thermal marker at low temperatures, as well as in the transition to low temperature metamorphism. Further we have tested the Raman spectroscopy against existing vitrinite reflectance data to corroborate interpretation of the Raman spectra, and to demonstrate the efficacy of Raman spectroscopy as a thermal marker.

The Raman data presented here is the first account of low temperature Raman spectra of carbonaceous materials being applied to fold and thrust belts. The data corroborate previous work and indeed allow us to view for the first time, Raman as an integrated and valuable tool for evaluating the thermal evolution of organic matter in many geological settings, least of which is the application from low maturity through to higher grade metamorphic assemblages. We have shown how Raman spectroscopy of carbon to low temperature materials can be used to support and interpret fold and thrust processes and their resultant thermal loads.

\section{Conclusions}

Raman spectroscopy was successfully applied to a suite of samples across the northern part of the French Sub-Alpine chain. Our results show, that:

(I) Thermal predictions from Raman can be cross-tied, and are in agreement with, vitrinite reflectance data from previous authors.

(II) NW Subalpine chains record significant variations in peak temperatures, ranging from 75 $-300^{\circ} \mathrm{C}$.

(III) The outlying (western parts of the thrust belt likely achieved peak temperatures during burial beneath the accumulated foredeep sediments. In contrast, the more internal (eastern) parts of the subalpine chain achieved high peak temperatures because of the emplacement of the Prealpine thrust sheets. In both settings, peak temperatures were achieved before the development of the local fold-thrust structures that host our samplesites. 
(IV) Raman is a relatively quick and effective tool for analysing lithologies with geological temperatures less than $300^{\circ} \mathrm{C}$ and can be particularly suitable to easily define the maturity stages of hydrocarbon generation.

Our application of Raman to the French subalpine chain allows us to open up further studies on not only fold and thrust belts, but anywhere we can see the value of extending our thermal alteration models to the early stages of thermal alteration, particularly where other techniques may not be suitable, or need to be corroborated.

This study demonstrates that Raman spectroscopy of organic material is a powerful tool for establishing peak palaeo-temperatures under the conditions appropriate for foreland fold and thrust belts and for hydrocarbon generation. As the technique is non-destructive, requires very small samples and is relatively simple to apply, it deserves to become a routine method to test models of structural evolution in thrust belts and for calibrating models of hydrocarbon generation in sedimentary basins.

\section{Acknowledgments}

Z. Crawford and A. Marpino were funded through the University of Aberdeen, School of Geosciences for MGeol and MSc project work. Bond, Butler and Watkins were supported through the Fold-Thrust Research Group, sponsored by Oil Search, Santos and Interoil.

\section{References}

Affolter, T., Faure, J. L., Gratier, J. P. and Colletta, B. (2008) 'Kinematic models of deformation at the front of the Alps: New data from map-view restoration', Swiss Journal of Geosciences, 101(2), pp. 289303.

Aldega, L., Corrado, S., Carminati, E., Shaban, A. and Sherkati, S., 2014. Thermal evolution of the Kuh-eAsmari and Sim anticlines in the Zagros fold-and-thrust belt: implications for hydrocarbon generation. Marine and petroleum geology, 57, pp.1-13.

Allen, P. A., and J. P. Bass, (1993) 'Sedimentology of the upper marine molasse of the Rhone- Alps region, eastern France: Implications for basin evolution', Eclogae Geologicae Helveticae, v. 86, p. 121-172.

Aubouin, J., Le Pichon, X. and Monin, A. S. (1986) 'Evolution of the Tethys', Part II: Maps. Tectonophysics, 123, plates I-X.

Balestra, M., Corrado, S., Aldega, L., Morticelli, M.G., Sulli, A., Rudkiewicz, J.L. and Sassi, W., 2019. Thermal and structural modeling of the Scillato wedge-top basin source-to-sink system: Insights into the Sicilian fold-and-thrust belt evolution (Italy). Geological Society of America Bulletin.

Barker C.E., Pawlewicz M.J. (1986) The correlation of vitrinite reflectance with maximum temperature in humic organic matter. In: Buntebarth G., Stegena L. (eds) Paleogeothermics. Lecture Notes in Earth Sciences, vol 5. Springer, Berlin, Heidelberg 
Barker, C. E., Lewan, M. D., and Pawlewicz, M. J., 2007, The influence of extractable organic matter on vitrinite reflectance suppression: A survey of kerogen and coal types: International Journal of Coal Geology, v. 70, p. 67-78, doi:10.1016/j.coal.2006.03.005.

Barfety, J.C. \& Gidon, M. (1984) 'Un exemple de sédimentation sur un abrupt de faille fossile: le Lias du versant Est du massif du Taillefer (Zone dauphinoise, Alpes occidentales)', Revue de géologie dynamique et de géographie physique, 25(4), 267-276.

Bellahsen, N., Mouthereau, F., Boutoux, A., Bellanger, M., Lacombe, O., Jolivet, L. and Rolland, Y. (2014) 'Collision kinematics in the western external Alps', Tectonics, 33(6), pp. 1055-1088.

Beyssac, O., Goffé, B., Chopin, C. and Rouzaud, J.N. (2002) 'Raman spectra of carbonaceous material in metasediments: A new geothermometer', Journal of Metamorphic Geology, 20(9), pp. 859-871.

Beyssac, O., Goffé, B., Petitet, J.-P., Froigneux, E., Moreau, M. and Rouzaud, J.-N. (2003) 'On the characterization of disordered and heterogeneous carbonaceous materials by Raman spectroscopy', Spectrochimica Acta Part A: Molecular and Biomolecular Spectroscopy, 59(10), pp. 2267-2276.

Bonal, L., Quirico, E., Bourot-Denise, M. and Montagnac, G. (2006) 'Determination of the petrologic type of CV3 chondrites by Raman spectroscopy of included organic matter', Geochimica et Cosmochimica Acta, 70(7), pp. 1849-1863.

BRGM (2015) Available at: http://www.brgm.eu/index.html

- Carte geologique de la France 1:50.000. Feuille 678, Annecy-Bonneville. Bureau des Recherches Geologiques et Minieres, Orleans.

- Carte geologique de la France 1:50.000. Feuille 703, St. Gervais Les Bains. Bureau des Recherches Geologiques et Minieres, Orleans.

- Carte geologique de la France 1:50.000. Feuille 2530, Thones. Bureau des Recherches Geologiques et Minieres, Orleans.

- Carte geologique de la France 1:50.000. Feuille 726, Albertville. Bureau des Recherches Geologiques et Minieres, Orleans.

Burkhard, M. (1988) 'L'Helvétique de la bordure occidentale du massif de l'Aar (évolution tectonique et métamorphique)', Eclogae Geologicae Helvetiae, 81(1), 63-114

Brolly, C., Parnell, J., Bowden, S., 2016. Raman spectroscopy: caution when interpreting organic carbon from oxidizing environments. Planet. Space Sci. 121, 53-59.

Busemann, H., Alexander, M.O. and Nittler, L.R. (2007) 'Characterization of insoluble organic matter in primitive meteorites by microRaman spectroscopy', Meteoritics \& Planetary Science, 42(7-8), pp. 1387-1416.

Bustin, R.M., 1991. Organic maturity in the western Canada sedimentary basin. International Journal of Coal Geology, 19(1-4), pp.319-358.

Butler, R.W.H. 1989. The geometry of crustal shortening in the Western Alps. In: Tectonic evolution of Tethyan Regions (ed. A.M.C. Sengor) Proceedings of NATO Advanced Study Institute, Kluwer, Dordrecht C259, 43-76. 
Butler, R.W.H. (1989) 'The influence of pre-existing basin structure on thrust system evolution in the western Alps', Geological Society, London, Special Publications, 44(1), pp. 105-122.

Butler, R.W.H. (1991) 'Hydrocarbon maturation, migration and tectonic loading in the western Alpine foreland thrust belt', Geological Society, London, Special Publications, 59(1), pp. 227-244.

Butler, R.W.H. 1992. Thrusting patterns in the NW French Subalpine chains. Annales Tectonicae 6, 150-172.

Butler, R.W., Bond, C.E., Cooper, M.A. and Watkins, H., 2018. Interpreting structural geometry in fold-thrust belts: Why style matters. Journal of Structural Geology, 114, pp.251-273.

Castiglioni, C., Tommasini, M., Zerbi, G., 2004. Raman spectroscopy of polyconjugated molecules and materials: confinement effect in one and two dimensions. Philosophical Transactions of the Royal Society of London. Series A: Mathematical, Physical and Engineering Sciences 362, 2425-2459.

Charollais, J. and M. Jamet (1990) 'Principaux resultats geologiques du forage Brizon 1 (BZN 1)', HauteSavoie, France: Memoire de la Societe Geologique de France, 156, p. 185- 202.

Coates, J. (2006). Interpretation of Infrared Spectra, A Practical Approach. In Encyclopedia of Analytical Chemistry (eds R. A. Meyers and M. L. McKelvy). doi:10.1002/9780470027318.a5606

de Graciansky, P.-C., Roberts, D.G., and Tricart, P., 2011, The Western Alps, from Rift to Passive Margin to Orogenic Belt: Developments in Earth Surface Processes, v. 14: Amsterdam, Elsevier, 398 p.

Deville, E. and Sassi, W. (2005) 'Contrasting thermal evolution of thrust systems: An analytical and modeling approach in the front of the western Alps', AAPG Bulletin, 90(6), pp. 887-907.

Di Donato, E., Tommasini, M., Fustella, G., Brambilla, L., Castiglioni, C., Zerbi, G., Simpson, C.D., Müllen, K., Negri, F., 2004. Wavelength-dependent Raman activity of D2h symmetry polycyclic aromatic hydrocarbons in the D-band and acoustic phonon regions. Chemical Physics 301, 81-93.

Doudoux, B. (1967) 'Nouvelle etude de la montagne du Semnoz pres d'Annecy'. Annales du Centre Universitaire, Savoie, 5, 121-143.

Doudoux B., Mercier de Lepinay B., Tardy M., 1982. Une interpretation nouvelle de la structure des massifs subalpins savoyards (Alpes occidentales): nappes de charriage oligocènes et déformations superposées. Comptes rendus. Acad. Sci. Paris, sll 295, 63-68.

Echavarria, L., Hernández, R., Allmendinger, R. and Reynolds, J., 2003. Subandean thrust and fold belt of northwestern Argentina: Geometry and timing of the Andean evolution. AAPG bulletin, 87(6), pp.965985.

Ferrari, A.C. \& Robertson, J. 2001. Resonant Raman spectroscopy of disordered, amorphous and diamond- like carbon. Physical Review B, 64, 075414.

Ferrill, D.A. and Groshong, R.H. (1993) 'Deformation conditions in the northern Subalpine chain, France, estimated from deformation modes in coarse-grained limestone', Journal of Structural Geology, 15(8), pp. 995-1006.

Ferrill, D.A. and Groshong, R.H. (1993) 'Kinematic model for the curvature of the northern Subalpine chain, France', Journal of Structural Geology, 15(3-5), pp. 523-541. 
Gidon, M. (2009) ‘Geol-Alp’ Available at: http://www.geol-alp.com/index.html

Gillcrist, R., Coward, M. and Mugnier, J.-L. (1987) 'Structural inversion and its controls: Examples from the Alpine foreland and the french Alps', Geodinamica Acta, 1(1), pp. 5-34.

Gratier, J.-P., M_enard, G., Arpin, R., 1989. Strain-displacement compatibility and restoration of the Chaines Subalpines of the western Alps. In: Coward, M.P., Dietrich, D., Park, R.G. (Eds.), Alpine Tectonics, vol. 45. Geological Society, London, pp. 65e81. Special Publications.

Guedes, A., Valentim, B., Prieto, A.C., Rodrigues, S., Noronha, F., 2010. Micro-Raman spectroscopy of collotelinite, fusinite and macrinite. International Journal of Coal Geology 83, 415-422.

Guedes, A., Valentim, B., Prieto, A., Noronha, F., 2012. Raman spectroscopy of coal macerals and fluidized bed char morphotypes. Fuel 97, 443-449.

Hackley, P. C., Ryder, R. T., Trippi, M. H., and Alimi, H., 2013, Thermal maturity of northern Appalachian Basin Devonian shales: Insights from sterane and terpane biomarkers: Fuel , v. 106, p. 455-462, doi:10.1016/j.fuel.2012.12.032.

Hackley, P.C. and Lewan, M., 2018. Understanding and distinguishing reflectance measurements of solid bitumen and vitrinite using hydrous pyrolysis: Implications to petroleum assessment. AAPG Bulletin, 102(6), pp.1119-1140.

HENRY, D.G., JARVIS, I., GILLMORE, G., STEPHENSON, M. \& EMMINGS, J.F. 2018. Assessing low-maturity organic matter in shales using Raman spectroscopy: effects of sample preparation and operating procedure. Interna- tional Journal of Coal Geology, 191, 135-151.

Hinrichs, R., Brown, M.T., Vasconcellos, M.A., Abrashev, M.V., Kalkreuth, W., 2014. Simple procedure for an estimation of the coal rank using micro-Raman spectroscopy. International Journal of Coal Geology $136,52-58$.

Homewood, P., P. A. Allen, and G. D. Williams (1986) 'Dynamics of the Molasse Basin of western Switzerland', International Association of Sedimentologists Special Publication, 8, p. 199-217.

Hutton, A. C., and Cook, A. C., 1980, Influence of alginite on the reflectance of vitrinite: Fuel , v. 59, p. 711-714, doi:10.1016/0016-2361(80)90025-3.

Jehlička, J. and Bény, C. (1992) 'Application of Raman microspectrometry in the study of structural changes in Precambrian kerogens during regional metamorphism', Organic Geochemistry, 18(2), pp. 211-213.

Kelemen, S., Fang, H., 2001. Maturity trends in Raman spectra from kerogen and coal. Energy \& Fuels 15, 653-658.

Kempf, O. and Adrian Pfiffner, O. (2004) 'Early tertiary evolution of the north Alpine Foreland basin of the Swiss Alps and adjoining areas', Basin Research, 16(4), pp. 549-567.

Knight, D.S. \& White, W.B. 1989. Characterization of diamond films by Raman spectroscopy. Journal of Materials Research, 4, 385-393. 
Kübler, B., Pittion, J. L., Heroux, Y., Charollais, J. and Weidmann, M. 1979. Sur le pouvoir reflectance de la vitrinitw dans quelques roches du Jura, de la Molasses et des Nappees prealpines, helvetigues et penniques. Eclog. Geol. Helv. 82, 765-793.

Lahfid, A., Beyssac, O., Deville, E., Negro, F., Chopin, C., Goffé, B., 2010. Evolution of the Raman spectrum of carbonaceous material in low-grade metasediments of the Glarus Alps (Switzerland). Terra Nova 22, 354-360.

Landis, C.A. 1971. Graphitisation of dispersed carbona- ceous material in metamorphic rocks. Contributions to Mineralogy and Petrology, 30, 34-45.

Lemoine, M. and Trümpy, R. (1987) 'Pre-oceanic rifting in the alps', Tectonophysics, 133(3-4), pp. 305320.

Lemoine, M., Bas, T., Arnaud-Vanneau, A., Arnaud, H., Dumont, T., Gidon, M., Bourbon, M., de Graciansky, P.-C., Rudkiewicz, J.-L., Megard-Galli, J. and Tricart, P. (1986) 'The continental margin of the Mesozoic Tethys in the western Alps', Marine and Petroleum Geology, 3(3), pp. 179-199.

Li, H., Wu, T., Ma, Z., and Zhang, W., 2004, Pressure retardation of organic maturation in clastic reservoirs: A case study from the Banqiao Sag, Eastern China: Marine and Petroleum Geology , v. 21, p. 10831093, doi:10.1016/j.marpetgeo.2004.07.005.

Liu, D., Xiao, X., Tian, H., Min, Y., Zhou, Q., Cheng, P., Shen, J., 2012. Sample maturation calculated using Raman spectroscopic parameters for solid organics: methodology and geological applications. Chinese Science Bulletin 58, 1285-1298.

Lünsdorf, N.K., 2016. Raman spectroscopy of dispersed vitrinite - methodical aspects and correlation with reflectance. International Journal of Coal Geology 153, 75-86.

LUPOI, J.S., FRITZ, L.P., PARRIS, T.M., HACKLEY, P.C., SOLOTKY, L., EBLE, C.F. \& SCHLAEGLE, S. 2017. Assessment of thermal maturity trends in Devonian- Mississippian source rocks using Raman spectroscopy: limitations of peak-fitting method. Frontiers in Energy Research, 5, 24.

Marques, M., Suárez-Ruiz, I., Flores, D., Guedes, A., Rodrigues, S., 2009. Correlation between optical, chemical and micro-structural parameters of high-rank coals and graphite. International Journal of Coal Geology 77, 377-382.

Marshall, A.O., Emry, J.R. and Marshall, C.P. (2012) 'Multiple generations of carbon in the apex Chert and implications for preservation of microfossils', Astrobiology, 12(2), pp. 160-166.

McTavish, R. A., 1978, Pressure retardation of vitrinite diagenesis, offshore northwest Europe: Nature , v. 271 , p. $648-650$, doi:10.1038/271648a0.

Molli, G.; Vitale Brovarone, A.; Beyssac, O.; Cinquini, I.2018RSCM thermometry in the Alpi Apuane (NW Tuscany, Italy): New constraints for the metamorphic and tectonic history of the inner northern Apennines. Journal of Structural Geology, Volume 113, p. 200-216.

Moss, S. (1992) 'Organic maturation in the french Subalpine chains: Regional differences in burial history and the size of tectonic loads', Journal of the Geological Society, 149(4), pp. 503-515. 
Muirhead, D.K., Parnell, J., Taylor, C. and Bowden, S.A. (2012) 'A kinetic model for the thermal evolution of sedimentary and meteoritic organic carbon using Raman spectroscopy', Journal of Analytical and Applied Pyrolysis, 96, pp. 153-161.

Muirhead, DK., Parnell, J., Spinks, S. \& Bowden, SA. 2017. 'Characterization of organic matter in the Torridonian using Raman spectroscopy'. Geological Society Special Publications, vol. 448, pp. 71-80.

MUIRHEAD, D.K., BOWDEN, S.A., PARNELL, J. \& SCHOFIELD, N. 2017. Source rock maturation due to igneous intrusion in rifted margin petroleum systems. Journal of the Geological Society, London, 174, 979,

Muirhead, D. K., Duffy, M., Schofield, N., Mark, N., \& Rowe, M. D. (2018). Making Oil From Magma. Geological Society Special Publications , 484.

Mumm, A.S., I_nan, S., 2016. Microscale organic maturity determination of graptolites using Raman spectroscopy. International Journal of Coal Geology 162, 96-107.

Negri, F., di Donato, E., Tommasini, M., Castiglioni, C., Zerbi, G., Müllen, K., 2004. Resonance Raman contribution to the $\mathrm{D}$ band of carbon materials: modeling defects with quantum chemistry. Journal of Chemical Physics 120, 11889-11900.

Nemanich, R.J. \& Solin, S.A. 1979. First and second order Raman scattering from finite-size crystals of graphite. Physical Review B, 20, 392-401.

Nibourel, L., Berger, A., Egli, D., Luensdorf, N. K., \& Herwegh, M. (2018). Large vertical displacements of a crystalline massif recorded by Raman thermometry. Geology, 46(10), 879-882.

O'HAVER, T. 2015. A Pragmatic Introduction to Signal Processing, https://terpconnect.umd.edu/ toh/spec trum/CurveFittingC.html

Philippe, Y., B. Colletta, E. Deville, and A. Mascle (1997) 'The Jura fold-and-thrust belt: Overall structural and mechanical aspects. Kinematic model deduced from map-balancing and regional implications' in W. Ziegler, ed., Peritethys Memoir 2: Paris, Editions du Museum d'Histoire Naturelle, v. 170, p. 235261.

Potgieter-Vermaak, S., Maledi, N., Wagner, N., Van Heerden, J., Van Grieken, R., Potgieter, J., 2011. Raman spectroscopy for the analysis of coal: a review. Journal of Raman Spectroscopy 42, 123-129.

Quirico, E., Rouzaud, J.N., Bonal, L., Montagnac, G., 2005. Maturation grade of coals as revealed by Raman spectroscopy: progress and problems. Spectrochimica Acta Part A: Molecular and Biomolecular Spectroscopy 61, 2368-2377.

Quirico, E., Montagnac, G., Rouzaud, J.., Bonal, L., Bourot-Denise, M., Duber, S. and Reynard, B. (2009) 'Precursor and metamorphic condition effects on Raman spectra of poorly ordered carbonaceous matter in chondrites and coals', Earth and Planetary Science Letters, 287(1-2), pp. 185-193.

Rahl, J.M., Anderson, K.M., Brandon, M.T. and Fassoulas, C., 2005. Raman spectroscopic carbonaceous material thermometry of low-grade metamorphic rocks: Calibration and application to tectonic exhumation in Crete, Greece. Earth and Planetary Science Letters, 240(2), pp.339-354.

Robertson, J. (1991) 'Hard amorphous (diamond-like) carbons', Progress in Solid State Chemistry, 21(4), pp. 199-333. 
Romero-Sarmiento, M.-F., Rouzaud, J.-N., Bernard, S., Deldicque, D., Thomas, M., Littke, R., 2014. Evolution of Barnett Shale organic carbon structure and nanostructure with increasing maturation. Organic Geochemistry 71, 7-16.

Rouzaud, J.N., Oberlin, A. and Beny-Bassez, C. (1983) 'Carbon films: Structure and microtexture (optical and electron microscopy, Raman spectroscopy)', Thin Solid Films, 105(1), pp. 75-96.

Sandford, S.A., Aléon, J., Alexander, C.M.D., Araki, T., Bajt, S., Baratta, G.A., Borg, J., Bradley, J.P., Brownlee, D.E., Brucato, J.R. and Burchell, M.J., 2006. Organics captured from comet 81P/Wild 2 by the Stardust spacecraft. Science, 314(5806), pp.1720-1724.

Sawatzki, G. G. (1975) 'Etude geologique et mineralogique des flyschs a grauwackes volcaniques du synclinal de Thones (Haute-Savoie, France)', Archives des Sciences, Geneve, 28, 18-368.

SCHITO, A., ROMANO, C., CORRADO, S., GRIGO, D. \& POE, B. 2017. Diagenetic thermal evolution of organic matter by Raman spectroscopy. Organic Geochemistry, 106, 57-67.

Schito, A. and Corrado, S., 2018. An automatic approach for characterization of the thermal maturity of dispersed organic matter Raman spectra at low diagenetic stages. Geological Society, London, Special Publications, 484, pp.SP484-5.

SCHMIDT, J.S., HINRICHS, R. \& ARAUJO, C.V. 2017. Maturity estimation of phytoclasts in strew mounts by micro- Raman spectroscopy. International Journal of Coal Geology, 173, 1-8.

Sissingh, W. 2001. Tectonostratigraphy of the West Alpine Foreland: correlation of Tertiary sedimentary sequences, changes in eustatic sea-level and stress regimes. Tectonophysics, 333, 361-400.

Steven E. Boyer , David Elliott (1982) 'Thrust systems', AAPG Bulletin, 66.

Tuinstra, F., Koenig, J.L., 1970. Raman spectrum of graphite. The Journal of Chemical Physics 53, 11261130.

Wilkins, R.W., Boudou, R., Sherwood, N., Xiao, X., 2014. Thermal maturity evaluation from inertinites by Raman spectroscopy: the 'RaMM' technique. International Journal of Coal Geology 128, 143-152.

Wopenka, B. \& Pasteris, J.D. (1993) 'Structural characterization of kerogens to granulite-facies graphite: Applicability of Raman microprobe spectroscopy', American Mineralogist, 78, 533-557.

Yui, T., Huang, E. and Xu, J. (1996) 'Raman spectrum of carbonaceous material: A possible metamorphic grade indicator for low-grade metamorphic rocks', Journal of Metamorphic Geology, 14(2), pp. 115124

Zhou, Q., Xiao, X., Pan, L., Tian, H., 2014. The relationship between micro-Raman spectral parameters and reflectance of solid bitumen. International Journal of Coal Geology 121, 19-25.

\section{Figure Captions:}


Figure 1. Summary of Raman spectral features and indicative workflow. A: Indicative Raman spectra from disordered carbon (top) to graphite (bottom), peak names and ratios. B: Evolution of Raman spectra from low maturity to high metamorphic grade with indicative temperature ranges (after Beyssac et al, 2002; Lahfid et al, 2010 and Schito et al, 2017). C: Example calculation from a sample in this study to generate final temperature (after Schito et al, 2017; 2018).

Figure 2: (a) Location of the study area; (b) Simplified structural map of the north-western Alpine foreland fold and thrust belt (modified after Butler (1991)); (c) Simplified geological map of the study are with location of cross sections (Fig. 2). A: Annecy; F: Faverges; LC: La Clusaz; T: Thones; R: Revard Thrust; V: Veyrier Thrust; S: Semnoz Thrust sheet; TD: Thones Depression; PA: Prealpine Nappe

Figure 3. Cross sections through the central Bornes ( $\left.A-A^{\prime}\right)$ and southern Bornes-northern Bauges (B-B') showing the structural geometries of the Mesozoic-Cenozoic succession. Key structures are labelled as follows: V: Veyrier Thrust; R: Revard Thrust; S: Semnoz thrust sheet; TD: Thones depression; AR: Araviz Ridge, an indicative prealpine nappe is also shown. Projected sample locations used for Raman Spectroscopy analysis are in blue, with calculated temperatures in red.

Figure 4. Representative stacked first order Raman spectra from across the study area.

Figure 5. Raman cross-plot of FWHM-G $\left(\mathrm{cm}^{-1}\right)$ and $\mathrm{G}$ band position $\left(\mathrm{W}_{\mathrm{G}}, \mathrm{cm}^{-1}\right)$ for all samples in this study. All data plot adjacent to the kerogen field after Wopenka \& Pasteris, (1993) (inset).

Figure 6. Geological map of study are with calculated Raman temperatures in red. Further temperatures are calculated from the \%Ro data from Moss (1992) (black boxes and black temperatures) and Deville \& Sassi (2006) (blue boxes and blue temperatures). Dashed black lines delineate the locations of the putative oil window and overmature zones after Moss (1992) and Deville and Sassi (2006). A: Annecy; F: Faverges; LC: La Clusaz; T: Thones; R: Revard Thrust; V: Veyrier Thrust; S: Semnoz Thrust sheet; TD: Thones Depression; PA: Prealpine Nappe.

Figure 7. Summary diagram showing the relationship between basin sedimentation and stratigraphic thickness, the timing and thickness of the prealpine nappe, and temperature and thermal maturation. Stratigraphic colours follow previous figures. The figure includes data from Moss (1992) on predicted sedimentary thicknesses for the Bornes area. Vertical scale (right handside $-\mathrm{km}$ ) refers to the predicted thickness of the prealpine nappe along section lines A-A' and B-B' (see Figure 1 for locations).

Table 1. Samples by locality with indicative stratigraphy and deconvolved Raman data. 


\begin{tabular}{|c|c|c|c|c|c|c|c|}
\hline Sample No. & Stratigraphy & G FWHM & $\begin{array}{c}\text { G Peak Position } \\
\left(\mathrm{W}_{\mathrm{G}}\left(\mathrm{cm}^{-1}\right)\right)\end{array}$ & $I_{D} / I_{G}$ & TOC (\%) & Temperature $\left({ }^{\circ} \mathrm{C}\right)$ & \pm \\
\hline 1 & Oligocene & 79.91 & 1590.64 & 0.21 & 3.36 & 75 & 10 \\
\hline 2 & Eocene & 60.70 & 1600.03 & 0.38 & 0.19 & 75 & 10 \\
\hline 3 & Barremian & 60.44 & 1594.95 & 0.56 & 0.06 & 90 & 10 \\
\hline 4 & Hauterivian & 54.84 & 1597.01 & 0.41 & 0.30 & 90 & 10 \\
\hline 5 & Val-Be & 51.89 & 1600.35 & 0.35 & 0.14 & 120 & 8 \\
\hline 6 & Barremian & 65.65 & 1595.44 & 0.30 & 0.03 & 90 & 10 \\
\hline 7 & Oligocene & 52.88 & 1600.96 & 0.31 & 0.45 & 115 & 9 \\
\hline 8 & Eocene & 50.74 & 1601.43 & 0.28 & 0.15 & 125 & 12 \\
\hline 9 & Oxfordian & 44.45 & 1602.39 & 0.66 & 0.34 & 300 & 18 \\
\hline 10 & Cal-Bat & 44.46 & 1603.03 & 0.62 & 0.54 & 300 & 20 \\
\hline 11 & Eocene & 75.86 & 1594.07 & 0.36 & 0.05 & 100 & 12 \\
\hline 12 & Tit-Kimm & 55.04 & 1599.96 & 0.36 & 0.08 & 115 & 5 \\
\hline 13 & Tit-Kimm & 56.77 & 1601.07 & 0.31 & 0.08 & 115 & 5 \\
\hline 14 & Hauterivian & 47.50 & 1602.48 & 0.34 & 0.23 & 115 & 8 \\
\hline 15 & Val-Be & 47.01 & 1600.09 & 0.27 & 0.90 & 120 & 5 \\
\hline 16 & Tit-Kimm & 54.92 & 1599.59 & 0.32 & 0.09 & 120 & 5 \\
\hline 17 & Oxfordian & 41.14 & 1603.55 & 0.44 & 0.09 & 260 & 20 \\
\hline 18 & Cal-Bat & 44.01 & 1602.75 & 0.55 & 0.19 & 260 & 15 \\
\hline
\end{tabular}

